\title{
TİP 1 PLAZMINOJEN EKSİKLİĞİNE BAĞLI BİR LİGNÖZ KONJONKTIVIT OLGUSUNDA TANI VE TEDAVİ YAKLAŞIMI
}

\author{
Diagnosis and Treatment Approach in a Case of Ligneous Conjunctivitis \\ Due to Type 1 Plasminogen Deficiency
}

\author{
Merve DURGUT ${ }^{1}$, Nesrin Büyüktortop GÖKÇINAR ${ }^{1}$, Tevfik OĞUREL ${ }^{1}$, \\ Meryem ALBAYRAK ${ }^{2}$, Pinar ATASOY ${ }^{3}$
}

\author{
${ }^{I}$ Kırlkkale Üniversitesi Tip Fakültesi, Göz Hastalıkları A.D., KIRIKKALE, TÜRKIYE \\ ${ }^{2}$ Kırlkkale Üniversitesi Tip Fakültesi Çocuk Hematoloji B.D., KIRIKKALE, TÜRKIYE \\ ${ }^{3}$ Kırıkkale Üniversitesi Tip Fakültesi Patoloji A.D., KIRIKKALE, TÜRKIYE
}

Lignöz konjonktivit konjonktivada odunsu yalancı membran oluşumuyla seyreden ve nadir görülen kronik bir hastalıktır. Genellikle otozomal resesif kalıtımlı tip 1 plazminojen eksikliğine bağlıdır. Plazminojen eksikliği fibrinolizis ve yara iyileşmesi bozukluğuna neden olur. Minör travmalar yoğun fibrin ve inflamatuar hücre birikimi gösteren membran oluşumlarını tetikler. Bu membranlar konjonktivada veya vücutta diğer mukozal yüzeylerde ortaya çıkabilir. Tedavide topikal siklosporin, taze donmuş plazma, trombin inhibitörü gibi ajanlar kullanılmasına rağmen nüksler görülebilmektedir. Bu yazıda, 6 yaşında bir lignöz konjonktivit olgusunda tanı ve tedavi yaklaşımını sunmayı amaçladık. Olgumuzda serum plazminojen seviyesi düşüktü $(3.4 \mathrm{mg} / \mathrm{dl})$. Eksize edilen membranların histopatolojik incelemesinde eozinofilik amorf materyal birikimi ile yoğun nötrofil baskın iltihabi hücre infiltrasyonu saptandı. Topikal \%0.1'lik deksametazon ve \%2'lik yüksek konsantrasyonda hazırlanan siklosporin tedavisine iyi yanıt alınd ve 4 y1llık takip süresinde nüks görülmedi. Konjonktivit tablosunun sistemik bir hastalığın göstergesi olabileceği akılda tutulmalı ve şüpheli vakalarda etiyolojik faktörler araştırılmalıdır.

nahtar Kelimeler: Lignöz konjonktivit, odunsu konjonktivit, plazminojen eksikliği, siklosporin.
Ligneous conjunctivitis is a rare chronic disease that is characterized with woody pseudomembrane formation in conjunctiva. It is usually due to autosomal recessive inheritance of type 1 plasminogen deficiency. Plasminogen deficiency results in impaired fibrinolysis and wound healing. Minor traumas trigger the formation of intense fibrin and inflammatory cell membrane deposits. These membranes may appear on conjunctiva or other mucosal surfaces in the body. Despite the use of topical cyclosporin, fresh frozen plasma and thrombin inhibitor, recurrences can be observed. In this article, we aimed to present a diagnostic and therapeutic approach for a 6-year-old ligneous conjunctivitis. His serum plasminogen level was low (3.4 mg/dl). Histopathological examination of expelled membranes revealed dense inflammatory cellular infiltrate with neutrophil dominance with eosinophilic amorphous material accumulation. Topical $0.1 \%$ dexamethasone and $2 \%$ high concentration of cyclosporine treatment were well tolerated and no recurrence was observed at 4 years follow-up. The etiologic factors should be investigated in mindful and suspicious cases where the conjunctivitis table may be indicative of a systemic disease.

Keywords: Cyclosporin, ligneous conjunctivitis, plasminogen deficiency 


\section{GİRIŞ}

Lignöz konjonktivit tarsal konjonktivada fibrin içerikli yalancı membran oluşumuyla seyreden ve nadir görülen bir hastalıktır. Diğer adı odunsu konjonktivittir (1). Etiyolojide esas sebep otozomal resesif kalıtımlı tip 1plazminojen eksikliğidir. Nadiren antifibrinolitik tedavi, ateşli hastalık, lokal enfeksiyon, travma ve kimyasal yanık ile tetiklenebilmektedir (1). Avrupa ülkelerinde milyonda 1-2 kişide görülürken ülkemizde akraba evliliklerine bağlı olarak daha sık görüldüğü tahmin edilmektedir (1). Lignöz konjonktivit otozomal resesif kalıtımlı tip 1 plazminojen eksikliğinin en sık görülen klinik bulgusudur. Plazminojen eksikliği vücutta göz dışındaki mukozal yüzeyleri de etkileyerek dişeti, solunum yolu, kulak, vajina ve gastrointestinal sistem tutulumu ve hidrosefali yapabilmektedir (1).

$\mathrm{Bu}$ yazıda kliniğimize lignöz konjonktivit ile başvuran bir çocuk olguda tanı ve tedavi yaklaşımımızı sunmak istiyoruz.

\section{OLGU}

6 yaşında erkek hasta sol gözünde kızarıklık, akıntı ve yabancı cisim hissi şikayeti ile Kırıkkale Üniversitesi Tıp Fakültesi Hastanesi Göz Hastalıkları Polikliniği'ne başvurdu. Şikayetlerinin, gözüne minör bir travma aldıktan sonra başladığı öğrenildi. Bunun dışında diş çürüğü, s1k üst solunum yolu enfeksiyonu geçirme ve akraba evliliği öyküsü mevcuttu. Anne ve babası haladayı çocukları idi. Oftalmolojik muayenede görme keskinliği her iki gözde tamdı. Her iki gözde yoğun mukoid sekresyon ve göz kapağ1 ödemi mevcuttu. Üst ve alt göz kapakları çevrildiğinde tarsal konjoktivanın üzerini kaplayan parlak sarı-pembe renkli membran oluşumları izlendi (Resim 1). Olgunun diğer ön ve arka segment göz muayenesi doğaldı. Membranlar steril bir forseps yardımıla \%0.5'lik Proparakain $\mathrm{HCl}$ ile topikal anestezi altında soyularak mikrobiyolojik ve patolojik inceleme için laboratuvara gönderildi. Membranlar odunsu yapıda sert ve kalındı. Ancak, ciddi bir kanama ve yapışıklık olmadan rahatlıkla soyulabildi. Tipik odunsu görünümde ve bilateral yerleşimli olan bu yalancı membranlar klinik olarak lignöz konjonktivit ile uyumluydu. Membranların histopatolojik incelemesinde materyalin tümünün nötrofilik infiltrasyon içeren fibrin kitlesi özelliğinde olduğu saptandı (Resim 2).

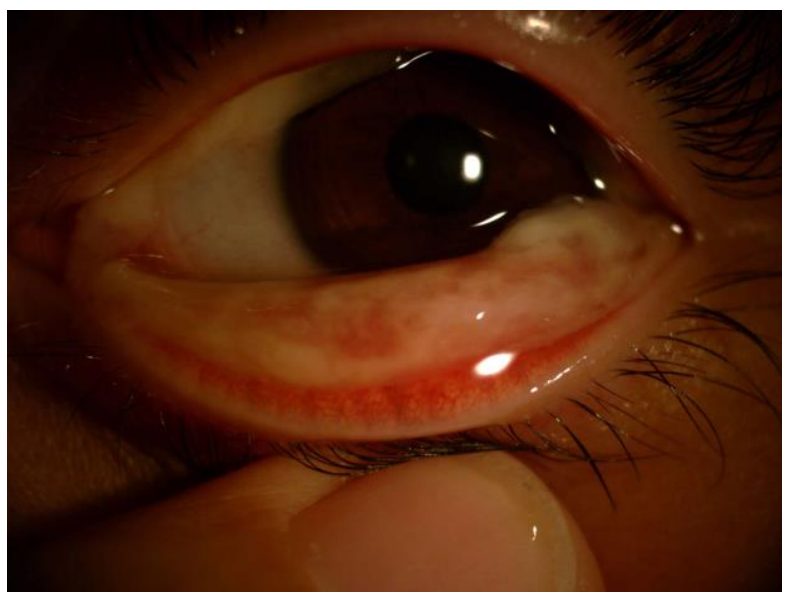

Resim 1: Sol göz ön segment fotoğrafi: inferior tarsal konjonktivada odunsu membran ve bulber konjonktivada hiperemi.

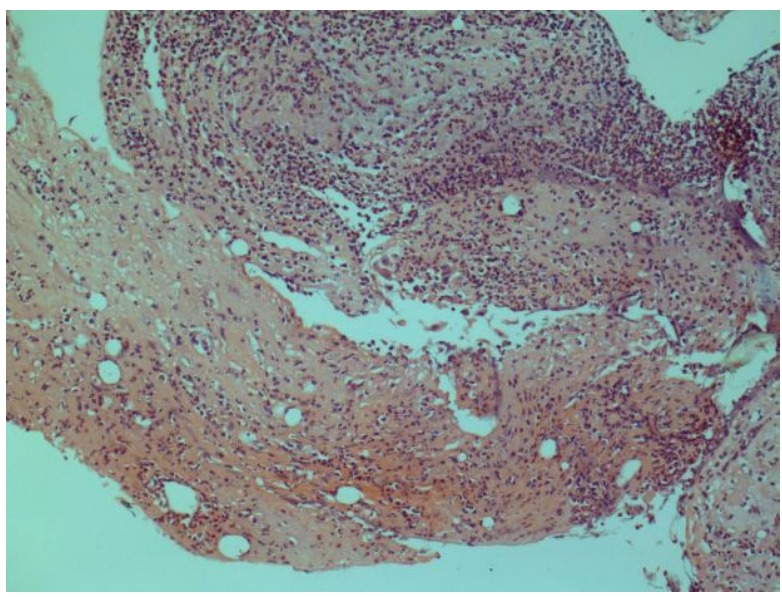

Resim 2: Membran histopatoloji fotoğrafi: Eozinofilik amorf materyal birikimi ile yoğun nötrofil baskın iltihabi hücre infiltrasyonu izlenmekte (H-E; X100)

Amiloid açısından yapılan histokimyasal calışmada krezil viyole boyaması negatif bulundu. Göz sürüntü kültüründe herhangi bir mikroorganizma üremedi. Bol polimorfonükleer lenfosit görüldü. Olgu sistemik ve etiyolojik yönden araştırılmak üzere Çocuk Hematoloji 
Bilim Dalı'na yönlendirildi. Fizik muayenede başka bir sorun saptanmadi. Serum plazminojen değeri $3.4 \mathrm{mg} / \mathrm{dl}$ idi (Normal aralık 10-15 mg/dl).

Membran eksizyonunu takiben \%0.1'lik deksametazon damla $4 \times 1$ ve yüksek konsantrasyonda \%2'lik siklosporin damla $4 \mathrm{x} 1$ şeklinde medikal tedaviye başlandi. $\mathrm{Bu}$ tedavi ile bulgular bir ay içerisinde tamamen düzeldi. Topikal ilaçlar azaltılarak kesildi. Olgunun dört yıllık takibinde nüks görülmedi.

\section{TARTIŞMA}

Olgumuzda olduğu gibi lignöz konjonktivitin en sık sebebi tip 1 plazminojen eksiklidir (1). Hastalığın patofizyolojisinde plazmin aracılı fibrinoliz yetmezliği rol oynamaktadır. Doku iyileşme sürecinin erken evrelerinde oluşan ürünlerin temizlenmesinde sorun vardır. İnsan korneası gözyaşı sıvısındaki plazminojen konsantrasyonunu kontrol edebilen, ekstrahepatik plazminojen sentez alanı olarak bilinmektedir. Plazminojen eksikliğine sahip hastalarda plazmin aktivitesinin olmaması, fibrinolizin bozulmasına ve fibrin bakımından zengin membranların oluşumuna neden olur. İnflamatuar hücre infiltrasyonu, fibroblast aktivasyonu ve yoğun fibrin içeren membranların oluşumuyla sonuçlanır (1). Lignöz konjonktivitte klinik görünüm tipik olmakla birlikte kesin tanı membranların histopatolojik olarak incelenmesiyle konulur. Histopatolojide albumin, fibrin ve immünglobülin $G$ içeren, eozinofilden zengin amiloid benzeri hyalinize bir membran ile birlikte granülasyon dokusu ve inflamatuar hücre birikimi izlenir (2). İmmünohistokimyasal incelemede, özellikle IL-2 reseptör ekspresyonu ve $\mathrm{T}$ hücrelerinin baskın olduğu inflamatuvar infiltrasyon gösterilmiştir (3). Siklosporin A, özellikle T-lenfositleri inhibe eden bir immün modülatördür (4). Lignöz konjonktivit tedavisinde membranın cerrahi eksizyonu sonrası topikal siklosporin uygulaması nüksü önlemede etkili bulunmuştur (5). Bizim olgumuzda da topikal siklosporin tedavisi uygulanmış ve 4 yıllık takip süresinde nüks gözlenmemiştir.

Olgumuzda yalnızca konjonktiva tutulumu olmakla birlikte hastalığın kornea tutulumu yaparak skar, vaskülarizasyon, keratomalazi, perforasyon ve körlüğe neden olduğunu bildiren çalışmalar bulunmaktadır (6). Kronik olgularda siklosporin dişında başka tedavi yöntemleri de uygulanmaktadır. Taze donmuş plazmadan topikal plazminojen hazırlanarak kronik membranların tedavisinde iyileşme gösterilmiştir (7). Daha şiddetli vakalarda amnion membran transplantasyonu ile konjonktiva rekonstrüksiyonu umut veren bir tedavi yöntemidir $(6,8)$. Ciddi konjenital tip 1 plazminojen defekti olan vakalarda direkt trombin inhibitörü, sentetik bir antikoagulan olan topikal Argatroban ve topikal plazma ile başarı elde edilmiştir (9). Olgumuzda topikal siklosporin ve steroid tedavisi ile tamamen iyileşme sağlandığından ek bir tedaviye ihtiyaç duyulmamıştır.

Lignöz konjonktivit kolay tanınan ancak tedavisi zor olabilen kronik bir hastalıktır. Topikal \%2'lik siklosporin tedavisi çoğu olguda etkili olmaktadır. Lignöz konjonktivit olguları nüksler açısından yakın takip edilmelidir. İleri tedavi hastalığın seyrine göre planlanmalıdır. Konjonktivit tablosunun sistemik bir hastalığın parçası olabileceği akılda tutulmalı ve etiyolojik faktörler araştırılmalıdır.

\section{KAYNAKLAR}

1. Schuster V, Seregard S. Ligneous conjunctivitis. Surv Ophthalmol. 2003;48:369-88.

2. Çelik T, Türkoğlu EB. Erişkin Hastada Tek Taraflı Lignöz Konjonktivit Olgusu. Türkiye Klinikleri J Ophthalmol. 2015;24(2):124-7.

3. Holland EJ, Chan CC, Kuwabara T, Palestine AG, Rowsey JJ, Nussenblatt RB. Immunohistologic findings and results of treatment with cyclosporine in ligneous conjunctivitis. Am J Ophthalmol. 1989;107:160-6. 
4. Tatlipinar S, Akpek EK. Topical cyclosporine in the treatment of ocular surface disorders. $\mathrm{Br} \mathrm{J}$ Ophthalmol. 2005; 89: 1363-7.

5. Coşkun M, Ayıntap E, Keskin U, İlhan Ö, Tuzcu E, Semiz H ve ark. Lignöz konjonktivitte membran eksizyonu sonrası topikal siklosporin-A kullanılan iki olgu. Turkiye Klinikleri J Ophthalmol. 2011;20:162-5.

6. Borabino S, Rolando M. Amniotic membrane transplantation in a case of ligneous conjunctivitis. Am J Ophthalmol 2004;137:752-753.

7. Watts P, Suresh P, Mezer E, Ells A, Albisetti M, Bajzar $\mathrm{M}$ et al. Effective treatment of ligneous conjunctivitis with topical plasminogen. Am J Ophthalmol. 2002;133;451-455.

8. Tok OY, Kocaoglu FA, Tok L, Burcu A, Ornek F. Treatment of ligneous conjunctivitis with amniotic membrane transplantation and topical cyclosporine. Indian J Ophthalmol. 2012; 60:563-6.

9. Suzuki T, Ikewaki J, Iwata H, Ohashi Y, Ichinose A. The first two Japanese cases of severe type I congenital plasminogen deficiency with ligneous conjunctivitis: successful treatment with direct thrombin inhibitor and fresh plasma. Am J Hematol. 2009;84(6):363-5. 